\title{
Project Management and Succesful Entrepreneurship Venture in Nigeria.
}

\author{
Iwueke Obinna C. Ph.D \\ Department of Business Administration and Management, \\ Federal Polytechnic Nekede, Owerri \\ Njoku, Uche \\ Department of Management Technology \\ Federal University of Technology, Owerri. \\ Nwaiwu Blessing $\mathbf{N}$. \\ Department of Management Technology \\ Federal University of Abuja, Abuja.
}

\begin{abstract}
This paper takes an empirical look at project management and small business entrepreneurship venture operations in Nigeria. It posit that project management background is essential to the setting up and good performance of entrepreneurship venture. The lack of knowledge of project management can create problems that will affect entrepreneurship venture growth and achievement of desirable objectives that lead to economic growth and development. The data used for the study was mainly from primary source through the use of questionnaire and personal interview and was complemented by secondary data. The study used Pearson chi-square statistical tools to analyses the data. The empirical results revealed that project management is not given adequate attention in the startup and operation of entrepreneurship ventures, this was attributed to lack of skills, knowledge and abilities and ignorance in the area of project management by individuals and institutions. Furthermore, the study established that some of the project management practices, approaches, competencies, and project managers' personal characteristics abound but how to apply them in entrepreneurship venture operations is a problem. The conclusion is that all stakeholders involved in entrepreneurship and business processes in Nigeria should be grounded in the basic elements of project management and know-how to apply them in entrepreneurship ventures. Recommendations are provided on how to galvanize the two concepts into desired results that will facilitate maximum results.
\end{abstract}

Keywords: project management, entrepreneurship ventures,, skills, responsibilities, and process

\section{INTRODUCTION}

It is widely accepted that national development and growth is dependent to a great extent on the development and growth of entrepreneurship ventures. Nigeria's economy has a potential for sustainable growth and development arising from such. Unfortunately, this situation which would have transformed our economy has not worked due to high rate of venture failures and termination which could be attributed to poor project management. Successful entrepreneurs who own ventures know that ventures are projects, to see their dreams of owning profitable businesses become a realities they know they must possess basic competencies in project management, and project managers' personal characteristics. Thus, starting a business and operating it successfully is a 'project' with desirable objectives to be achieved. 
Onwumere(2012)in quoting, steinioff and Burgers (1993) stressed that entrepreneurship is the ability to develop a new venture and apply managerial abilities to the success ofthe venture. Basically, project management is a strong managerial ability which encompasses every function of management - planning, organizing, directing, and controlling geared towards utilizing scarce resources to achieve desirable objectives.

Business Dictionary defined a business venture as a start-up entity developed with the intent of profiting financially with risk therein. Project and a venture can be used interchangeably. The only difference between them is the duration. Thus, Valencia (2007) stressed that project management which is the application of knowledge, skills, tools, and techniques to project activities to meet the project requirements is very critical to startup ventures and existing businesses.

Also, entrepreneurship ventures goes beyond a typical project life circle implying that while projects have expected durations businesses do not have expected duration and as a result, an entrepreneur is constantly involved in growing his business which can be described as business development consisting of new projects in the form of new or improved processes and product. Thus, entrepreneurs are expected to utilize project management practices, approaches and competencies to pursue entrepreneurial opportunities, lunch ideas to initial operations and conduct entrepreneurial activities.

On the business front in Nigeria, the situation is deplorable because there is an almost daily business failure notwithstanding the increased business startups. This demands a lot of attention to be paid to this failure rate of entrepreneurship ventures; new businesses formed compared with closures are consistently close in number. There are also incidences of lack of full understanding of risk involved which does not reduce the possibility of loss and increase the chances of success. Hatten (2006) opined that running a small business successfully involves much more than getting an idea, hanging out a sign, and opening for business the next day, rather, vision, resources, and a plan to take advantage of opportunity that exist are critical. All these are inherent in project management.

Ajam (2014), stated that entrepreneurship ventures possibly require project management at least at inception because entrepreneurs are expected to perform project management related functions during but not limited to the startup of their business. Ntamere(2006) corroborate the point when he stressed that business idea for startup is synonymous with a project idea which must pass through project appraisal that is like business plan for its feasibility and viability to be determined before the venture is setup. But, it is unfortunate that most ventures fail due to poor or lack of well-prepared business plan and lack of project management competencies.

Akanwa \& Agu (2010), were of the opinion that entrepreneurial ventures that translate from business ideas are projects ideas which must pass through project appraisal and phases of project for it to survive and be competitive in the dynamic business environment. They further stressed that business plan which starts from a business idea proves feasibility, attracts capital, and provides direction for the startup venture. These three functions are critical to the survival and success of any entrepreneurial venture. What this scenario suggests therefore is a state where project management is not given its rightful place in the setup and operation of startup and already existing ventures. Perhaps one can therefore posit that lack of project management competencies and project manager personnel characteristics is a major cause of venture startup failures in Nigeria which has been affecting the economy adversely. However, there is 
also the question of the basic project management, knowledge, skills, and abilities needed for small business operations. Also, the issue of how project management competencies can be given to entrepreneurs and small business owners. These fundamental questions will be the focus of this study.

\section{OBJECTIVE OF THE STUDY}

The main focus of this study therefore is the determination of the relationship between project management and entrepreneurship venture and whether project management influences the success of business venture which leads to economic growth and development. Specifically the study examined the perception of respondents in Abuja, Owerri and Umuahia with respect to project management competences and their application to venture start-up and already existing businesses.

\section{STATEMENT OF HYPOTHESIS}

In order to realize the objectives of this study the following hypotheses have been formulated: Ho 1: Project management soft skills do not have significant relationship with the operation of entrepreneurial ventures.

$\mathbf{H}_{\mathbf{A}}$ 1: Project management soft skills have significant relationship with the operation of entrepreneurial venture. There is no significant relationship between.

$H_{0}$ 2: there is no significant relationship between Project management roles, responsibilities and process with entrepreneurial venture.

$\mathbf{H}_{\mathrm{A}}$ 2: there is a significant relationship between Project management roles, responsibilities and process with entrepreneurial venture.

\section{REVIEW OF RELATED LITERATURE}

Entrepreneurs should not just want to succeed temporarily; they should aim at sustainable success. Corney (2012), stated that entrepreneurship involves more than development of skills to grow a business together with the personal competencies to make it successful entrepreneur are expected to be innovative and being innovative means being original. An original means a first time which involves a start. To start an entrepreneur has to able to conceive and execute a workable plan. Once this plan has become a finished product, it is termed successful but needs to be sustained and continually developed the early stages of this venture is usually toughest, once gotten right, other phases fall into place, basically, this is when project management competencies, practices and approaches come to play.

Taylor and Watling (1978) defined project management as two things: a management arrangement and a system of management techniques. An organization venture for managing projects, which involved the application of modern tools and techniques in planning, financing, implementing, monitoring, controlling and co-coordinating unique activities or tasks to produce desirable output in accordance with the predetermined objectives within the constraints of time and cost.

Iwueke (2016) opined that project management is not a prerogative of construction companies as often perceived by many individuals, but presently many aspects of business (Like innovating a new product, implementing a new product, implementing new production process etc) are treated as projects and managed as invariably, an average manager spends more time in project related issues.

Nagaraja (2010) in corroboration of the above stressed that project management consist of project planning scheduling, implementation, controlling and monitoring which are the core business operations. 
Ntamere (1995) x-rayed the overview of project management to encompass time, resources, cost performance which is geared towards good customer relations the thrust of every business that want to survive, be competitive and achieve desirable objectives hence, project management as a technique is assuming greater importance since it aims at optimum utilization of resources in projects execution which are prime movers of economic development.

Riggs (2004) stated that project are one of the ways in which human creativity is most effectively harnessed to achieve tangible, lasting results through its organization and individual change and adapt to take advantage of new opportunities or counter threats. In a world in which business competitiveness is based on search of new products and ways to do things every individual and organization can improve their prospects and ways by always thinking the place of project in the current situation. No wonder, little and Mireless (2009), were of the view that a project is any scheme for investing resources which can be reasonably analyzed and evaluated as an independent unit. Thus corroborating the project management institute (PMI) which defined a project as a temporary endeavor undertaken to create a unique product or service. Invariably, project and project management are needed aspects of entrepreneurial start - up and existing ventures.

\section{Rationale}

Okafor and Onwumere (2012) discovered that in a developed country like the United States of America, 56\% of new business fail to survive beyond their first three years in existence U.S small Business Administration Office of Advocacy, 2009). Excessive focus on products and services rather than planning other management functions, has been identified as the major reason why 60-70 percent of small and medium (SMES) fail in their first three years of starting operations in Nigeria. This was the conclusion of experts, drawn from government agencies, oil and gas sector, other sectors of the economy who participated in the workshop on tools for sustainable entrepreneurship held at Lagos, Nigeria 2010. Their research showed that small business in developed developing nations fail due to weak general management and project management like poor planning and financial management. The failure rate for new business seems to be around $70 \%$ to $80 \%$. In the first year and only about half of those who survive the first year will remain the next five years.

According to Akanwa (2012), the moment an entrepreneur undertakes a venture which involves people, time, money and other resources; he becomes a venture or project manager. If an entrepreneur is involved in several projects, he ought to have the requirement in managing projects. Thus there is a direct relationship between skills and performance. Since an entrepreneur has this business knowledge necessary to make project - based decisions that lead to bottom - line success, being the manager of his venture will save him time involved recruiting a project manager reduce cost and enable him to develop the skills of his staff while involving them in company projects.

Remirez (2013), argued that although entrepreneurs have distinctive traits portrayed in literature, it is possible to find several studies focusing on related characteristics from project managers. Also Lingdreen and Packendorff (2003) quoting Remirez (2013) noticed a similar opportunity in their project based view of entrepreneurship, where they argued in favour of considering entrepreneurial acts as temporary series of events with time - limits and team action which in consequence could be analyzed and researched in terms of projects. 
PrachanthKubsad who is a project manager at Cisco systems suggests that the collaboration and integration of entrepreneurship and project management practice to leverage upon them for increasing the success rate of projects which will in turn increase the return on investment for the organization and price reduction of products. He continued by saying that every genius idea needs to be barked with proper management and every management needs to have a thought process that leads to success, so if the best practices of both entrepreneurship and project management are applied in right sense and in right time, there will be no second thought that the venture or project will be successful. He concluded by saying that bringing in entrepreneurship in the organization culture and backed up with project management process will add great value to the business meaning that entrepreneurship will provide a sense of ownership and project management will be the driving force.

A look at most Nigerians institutions offering entrepreneurship as a degree or a certificate program shows that project management courses or classes are not included in their curriculum.

Okafor and Onwumere (2012) established that entrepreneurship education has not received the deserved attention in Nigerian Universities to start with a few, Enterprise Development Centre of Pan-Atlantic University in Nigeria offers a certificate in Entrepreneurship management. The same is obtainable in Federal University of Agriculture Makurdi, Nigeria's Centre for entrepreneurship Development, Covenant University Centre for Entrepreneurship Development Studies, University of Nigeria Nsukka's Entrepreneurship Centre and that of University of Benin among others.

In contrast most schools in United States such as the University of Southern California Marshal School of Business, Massachusetts Institute of Technology (MIT) and Univesity of Winsconsin, Parkside, incorporate project management or project related courses in their entrepreneurship programs. MIT students engage in practical projects to attract grants to their institute but more specifically to develop project management skills amongst other skills. This missing link in Nigeria institutions by extension translate in seminars and workshop organized and delivered for entrepreneurs and business owners leading to business failures and adverse effect on the economy.

We are already aware that most countries in the western world are developed and run a better economy despite the failure rate of small business enterprises in these countries within few years of startup. These countries operate capitalist economy as Nigeria claim to do also, which is founded on entrepreneurship and industrialization and most educational institutions in these countries offer project management courses in their entrepreneurship certificate programs and degree. It is high time Nigerian education institutions corrected this anomaly if optimum utilization of resources and best contributions are to be made by small and medium scale enterprises to the National economy.

\section{Personal Attribute of Project Manager And Entrepreneurs}

According to Dolfi and Andrew (2007) project managers have the trait to overcome impediments associated with the work environment, work with diverse team which makes them sociable and extroverts, accommodate change easily, multi task and manage resources more than any manager because they have to work with a project which cannot easily be changed without going through rigorous process and they are flexible in their leadership role.

Valencia (2007) quoting Bagozzi and Foxall (1995) stated that the originality of a project manager makes him a person of a high adaptive style who tends to present a limited number of 
implementable solutions to a problem and decision making. He identified administrative ability was the most important attribute for performance.

Also, Dvir et al (2006) stressed that project managers have inventor, enterprising personalities and are open to experiences.

Ramirez's (2013) drew the following conclusions from studies carried out by Rauch and Frese (2007),Zhoa etal (2010) and Brand statter (2011) respectively; Firstly, people who have traits of doing business (entrepreneurship traits) will most likely lean towards achievement, selfefficacy, innovativeness and proactive personality. Secondly, although people who take risks and are extroverts are more likely to have entrepreneurship intentions, people who take risks and are extroverts and emotionally stable are more likely to emerge and succeed as entrepreneurs. While risk is associated with entrepreneurship intentions ,it is not related to entrepreneurship performance and finally, behaviors such as innovation proactive personality, general efficacy, stress tolerance, need for autonomy and locus of control are significantly correlated to business creation and business success.

Nwokoro (2012) identified the following qualities of an entrepreneur; risk taking, creativity, responsibility, vision, self-confidence, originality, task-oriented, leadership, time management, achievement driven, information seeking, persistent and efficiency oriented.

Although the researchers above have listed significant attributes of project manager and entrepreneur, we have categorized these attributes under the attributes of successful project managers and entrepreneurs. Project managers and entrepreneurs must not possess these attributes to be project managers and entrepreneurs but they must possess these attributes to be termed successful in their professions and ventures.

\begin{tabular}{|l|l|}
\hline Attributes of successful project managers & Attributes of successful Entrepreneurs \\
\hline $\begin{array}{l}\text { Optimistic, result driven, sociable and } \\
\text { extroverts, team spirit, problem solvers and } \\
\text { change agents, multi taskers, and resource } \\
\text { managers, original, flexible, adaptive and risk } \\
\text { takers }\end{array}$ & $\begin{array}{l}\text { Motivation, self -efficacy, innovativeness, } \\
\text { stress tolerance, proactive personality; } \\
\text { take risks, extroverts, conscientious, open } \\
\text { and emotionally stable, need for autonomy } \\
\text { and locus of control, focus, creativity, } \\
\text { confidence, passion and sociable }\end{array}$ \\
\hline $\begin{array}{l}\text { We add that project managers should be } \\
\text { accountable, responsible, able to technically } \\
\text { select the right opportunity from many, hard } \\
\text { working, honest and stress tolerant }\end{array}$ & $\begin{array}{l}\text { Team spirit, accountability, responsibility, } \\
\text { courage, ability to select the right } \\
\text { opportunity from many, originality, vision, } \\
\text { task-oriented, hard working and honest }\end{array}$ \\
\hline $\begin{array}{l}\text { Administrative ability, decision making, leader, } \\
\text { inventor and enterprising personalities and are } \\
\text { open to experiences. }\end{array}$ & \multicolumn{2}{|l}{} \\
\hline
\end{tabular}

Both project managers and entrepreneurs have attributes that are similar. But entrepreneurs are more creative, proactive and innovative; as a result, they have high traits to discover opportunities than project managers while project managers have higher traits of exploiting (developing) entrepreneurship opportunities. Invariably, for an idea to be successful, it must be functional which is what a project manager will achieve. 
Although, it is a talent advantage for entrepreneurs to be able to select the right opportunity from many ideas, a project manager will perform an appropriate feasibility study or project plan to confirm that a selection is workable.

Also, even though to a great extent, personality drives entrepreneurship while competency drives project management. Competency outweighs personality because who you are can only be seen in what you do. Prashanth Kubsad who is a project manager at Cisco system believes that bringing in Entrepreneurship in organization culture and backed up with project management process will add great value to the business. Additionally, entrepreneurship provides a sense of ownership and project management will be a driving force.

We conclude that entrepreneurial traits are sufficient to conceive a business idea and probably start off one but may not be sufficient to succeed in one, while traits of a project manager may be sufficient to conceive a business idea but sufficient to start off one and probably succeed in it.

\section{Project Managers And Entrepreneurs Skills}

Without implementation no good idea can be realized. Having effective project management skills is crucial to any role in every industry. A good project manager maximizes resources, streamlines processes, controls costs, and delivers results.

According to Iwueke etal (2016) quoting Taylor (1998) identified the following as skills needed by successful project managers.

- Communication (listening and persuading or negotiation)

- Organization (planning, goal setting and analyzing)

- Team building (Empathy, motivation, spirit d corp.)

- Leadership (set example, energetic, vision, delegate, positive attitude)

- Coping skills (flexibility, creativity, patience, persistence)

- Technical skills (experience and project knowledge)

- Budgeting skills.

According to Kubsad (2014) the following are skills of a project manager that an entrepreneur needs to adapt to 


\begin{tabular}{|c|c|}
\hline Project management skills & Entrepreneurs needs \\
\hline $\begin{array}{l}\text { Shared vision } \\
\text { Well organized or planned execution } \\
\text { and control }\end{array}$ & $\begin{array}{l}\text { Both professionals share this skill. } \\
\text { Planning is must. Execution of ideas and } \\
\text { creating products out of it needs good } \\
\text { control and tracking of activities }\end{array}$ \\
\hline Good communicator & $\begin{array}{l}\text { To efficiently communicate ideas, vision } \\
\text { with all the stakeholders to get their buy } \\
\text { in. }\end{array}$ \\
\hline collaboration & To get along and work together \\
\hline Customer centricity & $\begin{array}{l}\text { Know your customer better and know } \\
\text { what they want }\end{array}$ \\
\hline Managing stakeholders & $\begin{array}{l}\text { Identify stakeholders issues and concerns } \\
\text { in timely manner and act upon them }\end{array}$ \\
\hline Balancing project constraints & $\begin{array}{l}\text { Balancing cost, time, risk, quality, scope } \\
\text { and stakeholders. }\end{array}$ \\
\hline More composed & $\begin{array}{l}\text { Complex problems needs analytical and } \\
\text { creativity skills. }\end{array}$ \\
\hline Delegate task & $\begin{array}{l}\text { In business you need to delegate task to } \\
\text { succeed. }\end{array}$ \\
\hline
\end{tabular}

\section{Project Managers And Entrepreneurs Roles And Responsibilities}

Project managers' roles and responsibilities are very similar to entrepreneurial process (feasibility study, planning, managing resources and executing plan) these processes are very similar for both staffing new venture and a project. They include:

- Entrepreneurs and project manager need to rightly manage the constraints (scope, time, cost, risk, quality and resources)

- Strategic decisions matter for both; should be driven by perception and resources.

- Both need to focus on exploring new opportunities for growth

- Innovativeness, proactive in dealing with new business ideas and opportunities.

From the foregoing project managers soft skills cuts across all types of entrepreneurship ventures and hence a requirement for successful operation of business. Kirsh (2000) in his study corroborated the above by laying emphasis on project managers' soft skills. Also Larger etal (2008) in their research found that the project manager hard skills have less impact on project performance compared to the soft skills. A project manager with higher soft skills may 
effectively manage a project even when he is not conversant with the project's technological or domain requirements. Hard or technical skills include technological skills, experience and domain expertise while soft skills are primarily concerned with managing and working with people and fostering inter and intra organizational relationships.

\section{DATA COLLECTION TECHNIQUES AND ANALYSIS METHOD}

A population of one hundred and fifty (150) persons from Owerri, Umuahia, and Abuja were used for the study. The sample size of 109 was derived using Taro Yamane formula $(n=N / 1+N$ $\left.(\mathrm{e})^{2}\right)$. A total of 109 questionnaire were shared using random sampling techniques

Both primary and secondary sources of data were used. Questionnaire administration and personal interview were the main instruments of data collection. The data obtained from the study was analyzed using both descriptive and inferential statistics. Inferential statistical technique of pearson chi-square $\left(\mathrm{X}^{2}\right)$ and contingency coefficient were also used test the hypotheses and extent of association of variables.

The Pearson chi square formula

$\mathrm{X}^{2}=(\mathrm{O}-\mathrm{E})^{2} / \mathrm{E}$

Where : $\mathrm{X}^{2}=$ value of chi-square

$\mathrm{O}=$ observed frequency

$\mathrm{E}=$ expected frequency

\section{Decision Rule}

- If calculated value of chi-square is less than the critical value we shall accept the null hypothesis, otherwise reject.

Test of Hypothesis one

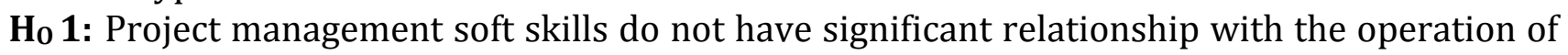
entrepreneurial ventures.

$\mathbf{H}_{\mathbf{A}}$ 1: Project management soft skills have significant relationship with the operation of entrepreneurial venture.

In order to test this hypothesis Question item 4, 5, and 6 were used

Table 1: whether project management soft skills are required in the operation of entrepreneurial ventures.

\begin{tabular}{|c|c|c|c|c|c|}
\hline & Which so & xills are you a & are of and practice & & Total \\
\hline $\begin{array}{l}\text { Whether } \\
\text { project } \\
\text { management } \\
\text { soft skills are }\end{array}$ & & $\begin{array}{l}\text { General } \\
\text { management } \\
\text { skill }\end{array}$ & $\begin{array}{l}\text { Human relation } \\
\text { and } \\
\text { communication } \\
\text { skill }\end{array}$ & $\begin{array}{l}\text { Financial and } \\
\text { marketing } \\
\text { management } \\
\text { skills }\end{array}$ & \\
\hline $\begin{array}{l}\text { required in the } \\
\text { operation of }\end{array}$ & $\begin{array}{l}\text { Strongly } \\
\text { agree }\end{array}$ & 32 & 20 & 0 & 52 \\
\hline entrepreneurial & Agree & 15 & 13 & 0 & 28 \\
\hline ventures. & Disagree & 0 & 1 & 14 & 15 \\
\hline & $\begin{array}{l}\text { Strongly } \\
\text { disagree }\end{array}$ & 0 & 1 & 2 & 3 \\
\hline Total & & 47 & 35 & 16 & 98 \\
\hline
\end{tabular}


Table 2: Chi-Square Tests for hypothesis one

\begin{tabular}{|l|l|l|l|}
\hline & Value & $\mathrm{df}$ & $\begin{array}{l}\text { Significance } \\
\text { (2 Sided) }\end{array}$ \\
\hline Pearson chi-square & 159.2 & 6 & .000 \\
Likelihood Ratio & 157.5 & 6 & .000 \\
Linear-by-Linear & 78.6 & 1 & .000 \\
Association & & & \\
\hline Number of valid cases & 98 & & \\
\hline
\end{tabular}

SPSS output, December, 2016.

It can be observed from the chi-square test result that the critical value of $\mathrm{X}^{2}$ at $5 \%$ level under $6 \%$ degree of freedom is 12.3 while the calculated value of chi-square distribution is 159.2 . We reject the null hypothesis, thus project management soft skills (competences) have significant relationship with the operation of entrepreneurial venture.

The statistical test proved that project manager' soft skills (General management skill, human relation and communication skill, and financial and marketing management skills) are critical to successful operation of entrepreneurial ventures.

$\mathrm{C}=\mathrm{X}^{2} / \mathrm{N}+\mathrm{N}^{2}=159.2 / 98+159.2=+0.7$

The calculated contingency coefficient of +0.78 signifies a very strong positive association between project management soft skills and successful entrepreneurial ventures.

\section{TEST OF HYPOTHESIS TWO}

Ho 2: Project management roles, responsibilities and processes do not have significant relationship with entrepreneurial venture success

$\mathbf{H}_{\mathbf{A}}$ 2: there is a significant relationship between Project management roles, responsibilities and processes with entrepreneurial venture success

In order to test this hypothesis question items 7, 8, and 9 were used.

Table 3: Whether project management roles, responsibilities and processes affect entrepreneurial venture success 
Table 4: Chi-square Tests for hypothesis two

\begin{tabular}{|l|l|l|l|}
\hline & Value & $\mathrm{df}$ & $\begin{array}{l}\text { Significance } \\
\text { (2 Sided) }\end{array}$ \\
\hline $\begin{array}{l}\text { Pearson chi-square } \\
\text { Likelihood Ratio } \\
\text { Linear-by-Linear } \\
\text { Association }\end{array}$ & 218.7 & 12 & .000 \\
& 79.8 & 12 & .000 \\
.000 & 1 & \\
\hline Number of valid cases & 98 & & \\
\hline
\end{tabular}

SPSS output, December, 2016.

The result of the chi-square test result that the critical value of $\mathrm{X}^{2}$ at $5 \%$ level under $12 \%$ degree of freedom $=21.01$ and the calculated $X^{2}=218.7$. Since the chi-square calculated is greater than the critical value of 21.01, we reject the null hypothesis and conclude that there is a significant relationship between Project management roles, responsibilities and processes with entrepreneurial venture success

$$
\mathrm{C}=\mathrm{X}^{2} / \mathrm{N}+\mathrm{N}^{2}=218.7 / 98+218.7=+0.829 .
$$

The calculated contingency coefficient of +0.829 signifies a very strong positive association

\begin{tabular}{|c|c|c|c|c|c|c|c|}
\hline & \multicolumn{6}{|c|}{$\begin{array}{l}\text { Whether project management roles, responsibilities and processes affect } \\
\text { entrepreneurial venture success }\end{array}$} & \multirow[t]{2}{*}{ Total } \\
\hline \multirow{5}{*}{$\begin{array}{l}\text { Whether project } \\
\text { management } \\
\text { roles, } \\
\text { responsibilities } \\
\text { and processes } \\
\text { affect } \\
\text { entrepreneurial } \\
\text { venture success }\end{array}$} & & $\begin{array}{l}\text { Strongly } \\
\text { agree }\end{array}$ & $\begin{array}{l}\text { Strongly } \\
\text { agree }\end{array}$ & $\begin{array}{l}\text { Strongly } \\
\text { agree }\end{array}$ & $\begin{array}{l}\text { Strongly } \\
\text { agree }\end{array}$ & $\begin{array}{l}\text { No } \\
\text { Response }\end{array}$ & \\
\hline & $\begin{array}{l}\text { Strongly } \\
\text { agree }\end{array}$ & 39 & 3 & 0 & 0 & 0 & 42 \\
\hline & Agree & 0 & 38 & 0 & 0 & 0 & 38 \\
\hline & Disagree & 0 & 9 & 6 & 1 & 0 & 16 \\
\hline & $\begin{array}{l}\text { Strongly } \\
\text { disagree }\end{array}$ & 0 & 0 & 0 & 0 & 2 & 2 \\
\hline Total & & 39 & 50 & 6 & 1 & 2 & 98 \\
\hline
\end{tabular}

between project management roles, responsibility and process with entrepreneurial venture and success.

\section{FINDINGS OF THE STUDY}

- Generally, there is low level of awareness of project management role in entrepreneurial venture operation in Nigeria. Rather the focus is on entrepreneurship aspect of business ventures.

- The Nigerian higher institutions curriculum and activities in the area of entrepreneurship has the missing link of project management in their activities. This has contributed to entrepreneurial venture failures due to lack of the knowledge, skills, and abilities of project management which are critical in entrepreneurial venture. 
- Most people in Nigeria are occupied with setting up and running ventures without knowing that ventures are projects which demands project management skills, knowledge and abilities.

- Owning and operating ventures for profit is more important to people than knowing and understanding the basic rudiments of project management that dove tail in entrepreneurship and are critical for business success in the Long run.

- There is a very strong positive association between project management soft skills and successful entrepreneurial ventures.

- There is significant relationship between project management role, responsibilities and process with entrepreneurial venture operations.

\section{CONCLUSION AND RECOMMENDATIONS}

In conclusion from the findings of this study, project management plays a very significant positive role in the success of entrepreneurial venture. Thus, the more it is integrated in the entrepreneurial venture process the more likely for the venture to succeed and contribute maximally to economic development. The rate of startup and venture failures in Nigeria can therefore be attributed to lack of inclusion of project management in the entrepreneurship programs and educational curriculum. It is therefore recommended:

- That for the government to realize development maximally from small business and entrepreneurial ventures the higher institution curriculum in entrepreneurship and other programs should integrate project management courses as per the need of various quarters, sectors while taking cognizance of national interest.

- Continuous training and development programmes in the area of project management should be organized for entrepreneurs and small business owners both in the private and public firms. This will enable them to understand the concepts, roles processes and responsibilities inherent in project management and practice them in their business venture.

- Entrepreneurship ventures should be started for sustainable reasons and maximum result. Thus, entrepreneurs should learn to be result driven, flexible, and team player, through acquisition of project management skills, knowledge and abilities.

- Entrepreneurs have to calculate project costs (business finance) and measure project (business) success. Learn exactly what costs must be measured to start a new business as well as determine the life cycle or project phases of business and how to deal with propose changes in the phases. 


\section{References}

Ajam M.A (2014) Project Management Foundation. Uk: AuthorHouse

Akanwa P.U and Agu C.N (2012). Entrepreneurship; Owerri Kosoko Press

Backer, B.N and Murphy D. C and Fisher D (2008) Project Management Handbook. Newyork: Van Nostrand Reinhold

Cooney T. M (2012) Entrepreneurship Skills for Growth Oriented Businesses. Workshop on Skills Development for SMEs and Entrepreneurship; Copenhagen.

Iwueke O C (2016) fundamentals of Project Management. Owerri; Cape Publishers

Nagaraja and Bhaskara (2011) Making Management Education Relevant to Business Needs, International journal of Business Education. Vol III

Ntamere C. C (1995) Project Management. Owerri; Alphabet Nigeria Publishers

Nwachukwu, V.O (2012) Business Statistics. Owerri; Emerald Press

Okafor and Onwumere (2012) Review for Valuation Models foor Private Enterprises in Nigeria. Research Journal of Finance and Accounting. Vol 3 No 10.

Pandia, R.M (1985) Excellence in Integration of Project Phases. PMI Proceedings; Denver, Vol 2

Riggs, J. L and Weist T.M (2004) Essentials of engineering Economics, Newyork; Mcgraw Hills.

Taylor, W. J and Watling, T.F (1979) Successful Project Management. London; Business Books. 